\title{
Impulse of Dividend Payment Decision: Evidence from Pharmaceutical Industry in Bangladesh
}

\author{
Md. Ariful Hoque ${ }^{1}$ \\ ${ }^{1}$ Department of Business Administration, International Islamic University Chittagong, Chittagong, Bangladesh \\ Correspondence: Md. Ariful Hoque, Lecturer in Finance, Department of Business Administration, International \\ Islamic University Chittagong, Kumira, Sitakunda, Chittagong 4318, Bangladesh.
}

Received: Decemebr 25, 2017

Accepted: January 8, 2018

Online Published: January 24, 2018

doi:10.5430/ijfr.v9n1p219

URL: https://doi.org/10.5430/ijfr.v9n1p219

\begin{abstract}
The dividend is the reward of shareholders of an organization in exchange for time and risk. For maximizing shareholder's wealth, optimum dividend payout ratio is essential. The prime objective of this paper is to identify impulse of dividend payment decision of listed pharmaceutical companies in Dhaka Stock Exchange of Bangladesh. Dividend payment decision is the dependent variable and profitability, firm's size, financial leverage, growth, and agency costs are taken as explanatory variables in this study. Collected secondary data are analyzed by econometrics software Eviews 8 through least square method. Formulated multiple regression models show value of R-square $\left(\mathbf{R}^{2}\right)$ is 0.604817 . $R$-square $\left(\mathbf{R}^{2}\right)$ value indicates explanatory variables explain $60.48 \%$ variation of the dependent variable. The study also reveals that profitability and agency cost positively influence the dividend payment decision and firm's size, financial leverage, growth negatively impact on the dividend payment decision of selected pharmaceutical companies. Among explanatory variables, profitability is not statistically significant at 5\% significant level whereas firm's size, financial leverage, growth and agency cost are found statistically significant at 5\% significant level. So this paper finds that listed pharmaceutical companies in Dhaka Stock Exchange must consider firm's size, financial leverage, growth and agency cost in their dividend payment decision.
\end{abstract}

Keywords: dividend decision, Dhaka Stock Exchange, pharmaceutical industry

\section{Introduction}

Corporate finance is a vast area of study where a financial manager has to take three major business decisions of an organization like financing decision, investment decision, and dividend decision. A firm or corporation becomes successful if financial executive takes these decisions prudently. Successful Corporation generates net income or profit after deducting all kinds of expenses. The company utilizes this profit or net income for various purposes like acquired new assets, repayment of outstanding debt, repurchase of outstanding common stock as well as distribution among shareholders. When a corporation decides to distribute their profit to shareholders, it is called dividend. A dividend is that portion of net income which a firm distributes among their shareholders as a return for their shares. That is, the dividend is the reward of the shareholders for investing their funds in the corporation. Dividend indicates the distribution of firm's earnings among shareholders (Pandey, 2004). Every company has a separate policy regarding the distribution of profit. The dividend policy of a corporation relays on many factors and current condition of that organization during dividend distribution as well as the industry where the organization incorporated. The goal of dividend policy is to satisfy the shareholders by maximizing their market value of an investment in the firm (Arnold 2008). Dividend decision seems to be a puzzle when it observes in a logical point of view (Black 1976). A financial executive has to take dividend decision prudently for minimizing corporation's upcoming expenses that will improve business performance and thereby ensure wealth maximization of shareholders. Dividend decision becomes corporate debate issue after giving presentation of a seminar paper by Miller and Modigliani in 1961. In this article, they represent that firm's value does not rely on dividend decision in a perfect capital market. (M\&M 1961) There is another school of thoughts who believes that dividend payment decision influence the market value of the corporation (Lintner \& John 1956, Gordon \& Myron 1959 and Walter 1963). Manufacturing sector plays a pivotal role in the development of Bangladesh economy through different export commodities in various foreign countries. In Bangladesh manufacturing sector comprises many industries like cement industry, steel industry, garment industry, food \& beverage industry, the pharmaceutical industry, ceramic 
industry, etc. Among these sectors, the pharmaceutical industry is one of the most crucial export-oriented sectors that contribute to developing Bangladesh economy. In manufacturing sector pharmaceutical industry is the second largest thrust sector after ready-made garment industries that export more than 125 countries after satisfying 98 percent of our country's local demand. Export value of pharmaceutical products is almost $\$ 82.11$ million during the fiscal year 2015-2016 (Bangladesh export promotion Bureau, 2015-2016). In the fiscal year, 2015-2016 market size of the pharmaceutical industry is Tk. 15,600 core. For that reason financial managers of the pharmaceutical industry have to take dividend decision carefully; otherwise, firms are not able to produce their pharmaceutical products in time to satisfy our local demand and export due to lack of sufficient funds or capital. Like any other industry, in pharmaceutical industry financial managers must also consider many factors that significantly influence the dividend distribution decision of the companies. If financial managers are not considered these factors, their dividend decision will not ensure the firm's wealth maximization goal. Though there are many research studies, have done for determining the factors affecting dividend decision of various industries in Bangladesh but there is no specific published research study for identifying the factors affecting dividend decisions of the pharmaceutical industry in Bangladesh. For that reason, this study is the researcher's little initiative to full fill this gap in the pharmaceutical industry of Bangladesh. That is, the prime objective of this paper is to find out the impulse of dividend payment decision of listed pharmaceutical companies in Dhaka stock exchange of Bangladesh.

The remaining part of this paper arranges as follows: section-2 literature review, section-3 research methodology and description of the variables employed in the study, section- 4 discussion of empirical results as well as the section- 5 conclusion.

\section{Literature Review}

There are ten unresolved issues in the literature of corporate finance whereas dividend decision is one of them (Brealey and Myers, 2010). Pay or not to pay dividend assists a firm to achieve their primary goal of wealth maximization. The company has to consider many factors in case of distributing a dividend. Over the decades there are various studies on the determinants of dividend decision. Some of these literatures are outlined below for identifying the variables and developing the hypothesis of this study.

At first partial adjustment model of dividends was investigated by the Lintner (1956). He envisaged that change in earnings was most pivotal determinants of a company's dividend decision. Lintner also tested his propositions and revealed that the partial adjustment model forecasted dividend payment more perfectly than naive models. Materially the result of the investigation disclosed that model described $85 \%$ of the changes in dividends for sample companies. Dividend becomes a matter of debate in corporate finance after the publication of a paper on dividend irrelevance theory in 1961 by Miller and Modigliani. Higgins (1972) studied the corporate dividend - savings decision. In this study, Higgins suggested that firm's fund requirement is one of the crucial factors affecting dividend decision. Debt financing is another factor of dividend payout ratio suggested by Higgins. McCabe (1979) examined the empirical affinity between investment and financing for a new look. In this paper, McCabe suggests new long-term debt negatively impact the amount of dividend paid. In this study, McCabe considered agency cost is also a determinant of dividend policy. Rozeff (1982) study on growth, beta and agency cost as determinants of firm's dividend payout ratios. The percentage of equity impound by insiders, the growth of realized \& expected future revenue of the firm, beta coefficients of the company as well as the number of common stockholders significantly related with dividend payout ratios by a model of a cross-sectional test. The output of the study refers that investment policy influences dividend policy. Pruitt \& Gitman (1991) examined financial managers of the 1,000 large scale US firms about interrelationship among investment, financing and dividend decisions in their firms. They found that payment of dividend influenced by present and previous year's earnings, the year to year volatility of earnings and extension in revenues. The study also suggested that earlier year earnings also influence on current dividends. Cahit Adaoglu (2000) revealed in his research that profitability or earning is the prime determinants of dividend payment decision in turkey. Kumar (2003) examined corporate governance and dividend payout in India. He found that positive relationship between dividends and earnings trend \& past investment as well as negative relationship between debt-equity ratios to dividend payout policy in India. Similar study done by Booth et al (2003) where result suggested that profitability, size, debt, risk along with tangibility \& growth impact on the dividend policy of the firm. Kania \& Bacon (2005) surveyed 10,000 publicly traded corporations where they considered factors motivating the corporate dividend decision. The result of the study revealed that profitability, growth, risk and liquidity significantly impact on the dividend payout ratio. Amidu and Abor (2006) performed a study on the determinants of dividend payout ratios in Ghana within 6-year periods. The result of the study showed that there was a statistically significant positive relationship between dividend payout ratio and earnings, cash flow \& tax as well as a substantial adverse relation between dividend payout ratio and risk, institutional ownership, development, and market value to the book 
value ratio. Anil and Kapoor (2008) investigate the determinants of dividend payout ratios on Indian information technology sector. They discovered that profitability has always been envisaged as a critical determinant of dividend payout ratio, whereas some other factors impact on the dividend payment decisions of an organization such as size, cash flows, market to book value ratio, corporate tax, and growth of sales. They showed that there is positive tie up between dividend payout ratios and profits, size and cash flows as well as an adverse interconnection between dividend payout ratios and corporate taxes. Gill et al. (2010) conduct a research work on determinants of dividend payout ratios: Evidence from the United States. In this study, they explored that sample corporation's dividend payout ratio is linearly tie-up with the margin of profit, debt-equity ratio and tax. Dividend payout ratios of sample firms in the services industry are collinear with the margin of profit, sales growth together with debt to equity ratio. In case of the manufacturing sector, they perceived that dividend payout ratio is related to profit margin, tax as well as markets to book ratio. Rizvi and Khare (2011) study on the determinants of dividend payout ratios of the Indian banking sector. They found that dividend payout ratios have a significant positive tie-up with EPS and significant adverse relationship with the stock beta. The study also revealed that insignificant correlation with cash flows from operations, debt-equity ratio and tax to earnings before tax ratio. Mehta A (2012) impart in his empirical analysis that firm's size and profitability are the significant ingredients of dividend decision of UAE companies over the study period. Musiega et al (2013) study on the determinants of dividend payout policy among 30 registered non-financial firms on Nairobi Securities Exchange for the periods of five years (2007 -2011). The result of the study shows that dividend payout policy positively correlated with return on equity, today's earnings and firm's growth whereas size and business risk consider as moderating variables increase the precision of significant variables from $95 \%$ to $99 \%$ among significant assessors of dividend payout policy. Nnadi et al (2013) survey the listed firms in the 29 stock exchanges in Africa subject to existing theoretical literature on the dividend policy. Findings of the study show that dividend policy determinants of African businesses are similar to those in most of economically developed countries. In African firms, agency cost is a specific important determinant of dividend policy. Nuhu E et al. (2014) outlined in their study that financial performance; debt financing, board size as well as the corporate tax are prime factors affecting dividend payout ratios where only board size is consistent in both financial and non-financial firms in Ghana. Jozwiak B.K. (2015) found in a study that dividend policy of Polish Listed Companies affected by profitability, liquidity, size, leverage of the firm. Abdulkadir R.I. et al. (2016) divulged in their investigation that behavior of the dividend payment of Nigerian dominated by the perception of shareholders, stock market behavior, profitability, interest rate, leverage, investment opportunities and prior dividend. Yusof Y. (2016) reveals in her study that earnings, firm size and investment have a significant positive impact on dividend policy of listed public companies in Malaysia whereas debt and large shareholders have a significant adverse influence. Banerjee, S. (2017) outline that liquidity, age, earning of each share as well as price to earnings ratio are statistically significant components of dividend payout ratio. Cristea, C, and Cristea, M (2017) demonstrated in a study that corporate financial performance \& liquidity positively related with dividend policy whereas economic condition growth, firm's size as well as financial leverage adversely associated with corporate dividend policy. Khan F.A. \& Ahmad N. (2017) revealed in their study that audit type liquidity, growth opportunities \& profitability are statistically significant determinants as well as taxation, risk; firm size \& leverage are statistically insignificant determinants of dividend payout of Pharmaceutical Companies of Pakistan Stock Exchange (PSX). There are some other factors like level of market capitalization, age \& growth of companies and profitability effect on the dividend policy of listed African firms. Identified variables from the above literature for this study given below: 


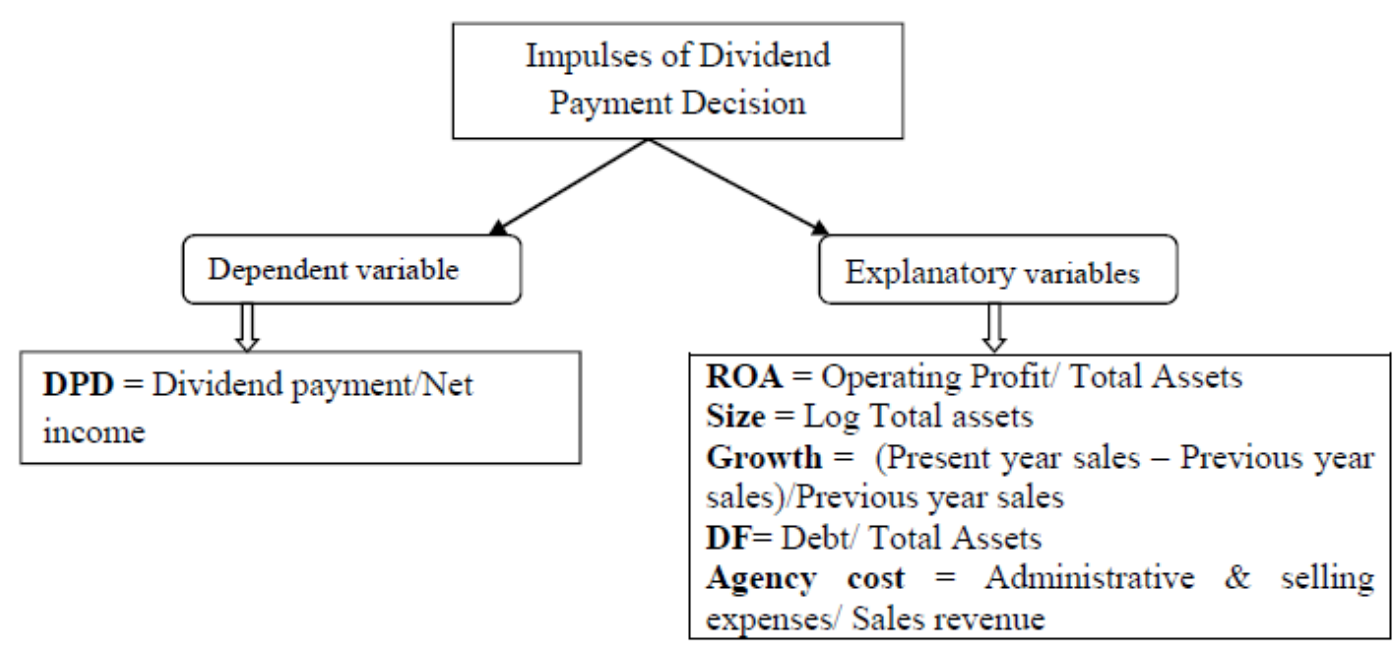

Following are hypotheses developed from above literature review of the previous study:

$\mathbf{H}_{1}$ : Return on assets (ROA) influence on the selected pharmaceutical companies' dividend payment decision (DPD).

$\mathbf{H}_{2}$ : Size of selected pharmaceutical companies' (size) influence on the dividend payment decision (DPD).

$\mathbf{H}_{3}$ : Annual growth rate (growth) of sample pharmaceutical companies' impact on the dividend payment decision (DPD).

$\mathbf{H}_{4}$ : Debt financing (DF) influence on the selected pharmaceutical companies' dividend payment decision (DPD).

$\mathbf{H}_{5}$ : Agency cost of sample pharmaceutical companies' (agency cost) impact on their dividend payment decision (DPD).

\section{Research Methodology}

Research methodology specifies how research will conduct on particular topics. The methodology consists of research design, sampling, data collection, and model specification as well as data analysis. Research design specifies the method of collecting and analyzing required data. This research is a causality study that represents a cause-effect tie-up between dependent variable and independent variables. That is, this type of research explores how explanatory variables influence on the dependent variable. Sampling is a way of collecting data from a target population. In this study, a purposive sampling technique is employed to select the sample. Here target population is the pharmaceutical industry of Bangladesh where a sample is selected that includes all the enlisted pharmaceutical companies in Dhaka stock exchange. There are eleven (11) enlisted pharmaceutical companies in Dhaka stock exchange but this study covers only nine (9) corporations whereas remaining two pharmaceutical companies (Central Pharmaceuticals Limited \& Beacon Pharmaceuticals Limited) excluded due to inadequate data. These two companies do not distribute the dividend during the study period (2010 to 2016) which is the key issue of this paper. Though there are 63 observations within selected Pharmaceutical companies, this article includes 61 observations. Remaining two observations are not incorporated due to unavailability of data. In this article dividend payment decision (DPD) is the proxy for selected firm's dividend decision which is also dependent variable. Profitability, firm's size, financial leverage; growth and agency cost are explanatory variables for chosen companies in this article. Whereas return on asset is considered as a proxy of profitability, log asset is taken as a proxy of firm's size; debt financing is the proxy of financial leverage, annual sales growth is the proxy of firm's growth and administrative \& selling expense is the proxy of agency cost. To assess the impact of identified independent variables on dependent variable researcher collects secondary data from Dhaka stock exchange and audited annual reports as well as financial statements of the selected Pharmaceutical companies. Collected data are coded, categorized, edited as well as organized in MS Excel for analysis. The least square method is used for analyzing secondary data where entire data set satisfies most of the assumptions of the multiple-regression model. Accumulated data set transfers from Ms excel to Eviews 8 for analysis that determines the influence of independent variables (return on assets, firm size, growth, leverage, corporate tax and agency cost) over the dependent variable (dividend payment decision). 
Developed hypothesis test at 5\% significant level. To trace the effect of independent variables on dependent variable following multiple regression models is deployed.

DPD $_{i, t}=\beta_{1}+\beta_{2}$ ROA $+\beta_{3}$ Size $+\beta_{4}$ Growth $+\beta_{5}$ DF $+\beta_{6}$ Agency Cost $+e_{i, t}$

Here, DPD = Dividend payment decision, ROA = Return on assets, Growth= annual sales growth of the company, $\mathrm{DF}=$ Debt financing, Agency cost $=$ cost required to employees of the firm.

\section{Analysis and Discussion}

The Goodness of fit of the model

\begin{tabular}{lllll}
\hline R-squared & Adjusted R-squared & F-statistic & Prob(F-statistic) & Durbin-Watson \\
\hline 0.604817 & 0.568891 & 16.83521 & 0.000000 & 0.905466 \\
\hline
\end{tabular}

Above table shows model summary where the value of the $R$-square $\left(\mathbf{R}^{2}\right)$ is 0.604817 . R-square $\left(\mathbf{R}^{2}\right)$ is the co-efficient of determination that explains the variability of a dependent variable due to independent or explanatory variables. In this study, the dependent variable is dividend payment decision whereas independent variables are profitability, firm size, firm's growth, debt financing, corporate tax and agency cost. Here the value of the R-square $\left(\mathbf{R}^{2}\right)$ is 0.604817 indicates $60.48 \%$ variation in the dependent variable, i.e., dividend payment decision explained by the independent or explanatory variables, i.e., profitability, firm size, firm's growth, debt financing, corporate tax and agency cost. The unexplained portion (39.52\%) exists in other factors that include in the error term of the econometric model. Adjusted R-square $\left(\mathbf{R}^{2}\right)$ value is 0.568891 which is consistent with the value of $r$-square $\left(\mathbf{R}^{2}\right)$ 0.604817. That is, there is little difference between the values of $R$-square $\left(\mathbf{R}^{2}\right)$ and adjusted $R$-square $\left(\mathbf{R}^{2}\right)$ which emphasis on the acceptability of the model. Here it is also said that all include explanatory variables in the model are relevant to explain the variation of the dependent variable. F-statistic Value is 16.83521 which are statistically significant at 5\% significant level that indicates goodness of fit of the model.

\section{Multiple regression models}

DPD $_{\mathrm{i}, \mathrm{t}}=109.54+0.06$ ROA -8.09 Size -0.65 DF -0.61 Growth +1.16 Agency Cost
$\begin{array}{ccccc}(\mathrm{Se}) & (31.47) & (0.33) & (2.99) \quad(0.20) & (0.24)\end{array}$
$\mathbf{R}^{2}=0.604817$

Within multiple regression models, dividend payment decision of selected pharmaceutical companies is the dependent variables and profitability, size, debt financing, annual growth, corporate tax rate as well as agency cost of selected pharmaceutical firms are explanatory variables. The developed hypothesis of these multiple regression models tested through t-test statistic at a 5\% significant level. The model shows that profitability which is indicated by ROA positively influence the dividend payment decision of selected companies which is concurrent with the study of Cahit Adagolu (2000), Kumar (2003), Booth et al. (2003). That is if profit increases one percent (1\%) dividend payment also increase $0.33 \%$ which refers more profitable firms declared more dividends for their shareholders. Though profitability influence positively dividend payment decision but this is not statistically significant at 5\% level of selected companies for the study period which indicates hypothesis -1 may be rejected. Firm's size negatively influences of the dividend payment decision of sample companies which is statistically significant at 5\% level which related to Booth et al. (2003), Anil and Kapoor (2008). Dividend payment reduces by $8.09 \%$ due to one percent $(1 \%)$ increases in firm's size. That is, dividend payment decreases due to enhancing firm's size. Financial leverage which is indicated by DF adversely influences the dividend declaration decision of the selected companies for the study periods which concurs with the study of McCabe (1979), Kumar (2003), Booth et al. (2003). There are two ways of financing one is debt financing which indicates financial leverage, and other is equity financing. The dividend is the expense of equity financing for issuing companies which decrease due to rising interest expense debt financing. If financial leverage or debt financing increase one percent (1\%) selected companies dividend payment reduces $0.65 \%$ that is statistically significant at $5 \%$ level. Annual growth of the firm adversely impacts on the dividend decision of the chosen companies which is significant at 5\% level. The adverse impact of yearly growth on dividend payment is related to Booth et al. (2003), Kania and Bacon (2005), Anil and Kapoor (2008), Musiega et al. (2013) study. Due to increasing operational volume selected companies required more funds for that reason pays less dividend. One percent (1\%) positive changes in firm's growth in If the annual growth of the selected companies increases one percent $(1 \%)$ dividend payment decrease $(1 \%)$. Another independent variable influence dividend decision of selected pharmaceutical companies is agency cost which consistent with the study of 
McCabe (1979), Nnadi et al. (2013). Agency cost is required a firm for minimizing agency conflict within the firm. Here dividend decision is positively affected by agency cost which is statistically significant at $5 \%$ significant level of the selected pharmaceutical companies for the period's study cover. Dividend payment increases $1.16 \%$ due to $1 \%$ changes in agency cost. From the above discussion, it is said that hypothesis- 1 is rejected at 5\% significant level whereas remaining hypothesis such as hypothesis-2, hypothesis-3, hypothesis-4, and hypothesis-5 accepted at 5\% significant level. That is, firm's size, financial leverage, annual growth and agency cost are statistically significant determinants, and profitability is insignificant of dividend payment decision of selected pharmaceutical companies listed on Dhaka stock exchange.

\section{Conclusion}

Dividend becomes a matter of debate among financial executive in the corporate world until researchers come to the same platform. Ever firm's must take dividend decision prudentially to maximize their shareholder's wealth. The prime concern of this research paper is to find out the impulse of dividend payment decision of listed pharmaceutical companies in Dhaka stock exchange that occupy more than $60 \%$ of the total market share of the pharmaceutical industries in Bangladesh. The study reveals that firm's size, financial leverage, annual growth and agency cost are statistically significant explanatory variables of dividend decision of selected pharmaceutical companies in our country whereas profitability is a statistically insignificant explanatory variable that also influences on dividend decision. Through some study like Booth et al (2003), Amidu and Abor (2006), Nuhu E et al. (2014), Abdulkadir R.I. et al. (2016), Cristea, C, and Cristea, M (2017), Khan F.A. \& Ahmad N. (2017) consider liquidity, Corporate tax, ownership structure also influence on dividend payment decisions. Due to unavailability of data and auto-correlation, these explanatory variables eliminated from the model used in this study. The study shows that dividend payment decision is positively affected by profitability and agency cost which concurred with the study of McCabe (1979), Nnadi et al. (2013) Cahit Adagolu(2000), Kumar(2003), Booth et al. (2003). That is if agency cost increases agency conflict will reduce that lead to more profit for the firm. More profitable companies pay more dividends for their shareholders. On the other hand, firm's size, financial leverage, and annual growth negatively influence the dividend decision of selected pharmaceutical companies. These findings of the study are consistent with Booth et al. (2003), Kania and Bacon (2005), Anil and Kapoor (2008), Musiega et al. (2013), Abdulkadir R.I. et al. (2016). So this study suggests that listed pharmaceutical companies in Dhaka stock exchange must have to consider firm's size, financial leverage, annual growth and agency cost in case of making their dividend decision. Through profitability also impact on dividend decision, but this one is not statistically significant for this study. This paper will help policymakers, financial executive and other stakeholders to take their dividend decision more precisely. This article also contributes to enriching current literature of dividend decision as well as becomes a guideline to enhance the existing study. In future the researchers may extend this study:

- Covering non-listed pharmaceutical companies in Bangladesh

- Covering more unexplained explanatory variables such liquidity, ownership, corporate governance etc.

\section{References}

Abdulkadir R.I. et.al. (2016). Dividend Payment Behaviour and its Determinants: The Nigerian Evidence. African Development Review, 28(1), 53-63. https://doi.org/10.1111/1467-8268.12166

Adaoglu, C. (2000). Instability in the Dividend Policy of the Istanbul Stock Exchange (ISE) Corporations: Evidence from an Emerging Market. Emerging Market Review, 1(3), 252-270. https://doi.org/10.1016/S1566-0141(00)00011-X

Aivazian, V., Laurence, B., \& Sean, C. (2003). Do Emerging Market Firms Follow Different Dividend Policies From U.S. Firms?. The Journal of Financial Research, 26, 371-387. https://doi.org/10.1111/1475-6803.00064

Amidu, M., \& Abor, J. (2006). Determinants of dividend payout ratios in Ghana. The Journal of Risk Finance, 7(2), 135-145. https://doi.org/10.1108/15265940610648580

Anil, K., \& Kapoor, S. (2008, May). Determinants of dividend payout ratios: A study of Indian information technology sector. International Research Journal of Finance and Economics, 15, 63-71.

Banerjee, S. (2017) Determinants of Dividend Policy of Listed Information Technology Companies in India. SCMS Journal of Indian Management, July - September.

Bangladesh export promotion Bureau, 2015-2016.

Black, F. (1976). The dividend puzzle. Journal of Portfolio Management, winter, 5-8. https://doi.org/10.3905/jpm.1976.408558 
Brealey, R. A., Myers, S. C., \& Allen, F. (2010). Principles of Corporate Finance (9th ed.). McGraw Hill International edition.

Cristea, C., \& Cristea, M. (2017). Determinants of corporate dividend policy: Evidence from Romanian listed companies. MATEC Web of Conferences 126, 04009. https://doi.org/10.1051/matecconf/201712604009

Gill, A., Biger, N., \& Tibrewala, R. (2010). Determinants of Dividend Payout Ratios: Evidence from United States. The Open Business Journal, 3, 8-14. https://doi.org/10.2174/1874915101003010008

Glen, A. (2008). Corporate Financial Management (4th ed.). Financial Times Pitman Publishing, London.

Gordon, M. J. (1959). Dividends, Earnings, and Stock Prices. Review of Economics and Statistics, 41, 99-105. https://doi.org/10.2307/1927792

Jozwiak, B. K. (2015). Determinants of Dividend Policy: Evidence from Polish Listed Companies. Procedia Economics and Finance, 23, 473-477. https://doi.org/10.1016/S2212-5671(15)00490-6

Kania, S. L., \& Bacon, F. W. (2005). What Factors Motivate the Corporate Dividend Decision?. ASBBS E-Journal, l(1), 97-107.

Khan, F.A., \& Ahmad, N. (2017). Determinants of Dividend Payout: An Empirical Study of Pharmaceutical Companies of Pakistan Stock Exchange (PSX). Journal of Financial Studies \& Research, 2017(2017), 16.

Kumar, J. (2003). Corporate Governance and Dividend Payout in India. Journal of Emerging Market Finance, 5(1), 15-58. https://doi.org/10.1177/097265270500500102

Lintner, J. (1956, May). Distribution of Incomes of Corporations among Dividends, Retained Earnings and Taxes. American Economics Review, 46(2), 97-113.

Mehta, A. (2012, March). An Empirical Analysis of Determinants of Dividend Policy - Evidence from the UAE Companies. Global Review of Accounting and Finance, 3(1), 18-31.

Miller, M., \& Modigliani, F. (1961, October). Dividend policy, Growth and the valuation of shares. Journal of Business, 34(4), 411-433. https://doi.org/10.1086/294442

Musiega, M. G., et al. (2013). Determinants of dividend payout policy among non-financial firms on Nairobi Securities Exchange, Kenya. International Journal of Science \& Technology Research, 2(10), 253-266.

Nuhu, E., et al. (2014, July). Determinant of dividend payout of financial firms and non-financial firms in Ghana. International Journal of Academic Research in Accounting, Finance and Management Sciences, 4(3), 109-118.

Pandey, M. (2004). Financial Management. Vikas Publishing House PVT Limited.

Pruitt, S. W., \& Lawrence, J. G. (1991, August). The Interactions between the Investment, Financing, and Dividend Decisions of Major U.S. Firms. Financial Review, 26(3), 409-430. https://doi.org/10.1111/j.1540-6288.1991.tb00388.x

Rizvi, S., \& Khare, S. (2011, February). Determinants of Dividend Payout Ratios - A Study of the Indian Banking Sector. Indian Journal of Finance, 5(2).

Rozeff, M. S. (1982). Growth, Beta and agency cost as determinants of dividend payout ratios. The Journal of Finance Research, V(3), Fall. https://doi.org/10.1111/j.1475-6803.1982.tb00299.x

Walter, J. E. (1963). Dividend Policy: It's Influence on the Value of the Enterprise. Journal of Finance, 18, 280-291. https://doi.org/10.1111/j.1540-6261.1963.tb00724.x

Yusof, Y. (2016). Determinants of dividend policy of public listed companies in Malaysia. Review of International Business and Strategy, 26(1), 88-99. https://doi.org/10.1108/RIBS-02-2014-0030 